\title{
O kondycji polskiej edukacji domowej jako społecznego „subimago” (albo o niebezpieczeństwach metaforyzacji)
}

\author{
KEY WORDS \\ Polish home \\ education, metaphor, \\ subimago
}

\begin{abstract}
Budajczak Marek, O kondycji polskiej edukacji domowej jako społecznego "subimago" (albo o niebezpieczeństwach metaforyzacji) [On the Condition of Polish Home Education as a Social Subimago (or on Dangers of Metaforization)]. Kultura - Społeczeństwo - Edukacja nr 2, 2012, Poznań 2012, pp. 53-60, Adam Mickiewicz University Press. ISBN 978-83-232-2528-7. ISSN 2300-0422

The paper gives an ironic and short, both empirical and normative analysis of current Polish home education intertwined with a metaanalysis of the role of metaphors in the language of the educational sciences. Entomological metaphor of subimago helps here in revealing the social status quo of the mentioned "home education" in Poland. One can describe socioeducational reality using different forms of expression. Metaphorization is one of them, not always adequate, but indispensable as well as cognitively pleasant.
\end{abstract}

Od dwudziestu już lat autor niniejszego opracowania ${ }^{1}$ zajmuje się tzw. „edukacją domową". W ramach owych wieloletnich edukacyjnych działań wobec członków własnej rodziny i wespół z nimi, a w szerokim kontekście oświatowym usiłował być „refleksyjnym praktykiem”, zaś względem osób z zewnątrz, zainteresowanych tą formą kształcenia, pełnił funkcję społecznika wspierającego ich rozumienie i działania w tym właśnie odniesieniu. Jako pracownik akademicki starał się też badać tę szczególną alternatywę edukacyjną, oferując szereg jej, w intencjach obiektywnych, konceptualizacji, choć ma świadomość tego, iż część spośród tych ujęć może być interpretowana jako ideologiczna, bo oparta jest na dość jednoznacznym systemie wartości politycznych i moralnych.

\footnotetext{
${ }^{1}$ Pierwotna wersja tego tekstu była prezentowana audytoryjnie, co może usprawiedliwiać jego retoryczną specyfikę, a szczególnie brak pełnego rozwijania kolejnych wątków, dla uszanowania inteligencji słuchaczy.
} 
Na początek, i gwoli naukowej przyzwoitości, podać trzeba generalne choćby określenie dla tytułowego zjawiska „edukacji domowej”. Na tę okoliczność przywołać można np. definicję zaproponowaną w suplemencie do Encyklopedii pedagogicznej XXI wieku. Edukacja domowa jest to w jej świetle „odmiana edukacji alternatywnej, w której rodzice lub prawni opiekunowie danego dziecka dobrowolnie przyjmują na siebie odpowiedzialność za zapewnienie mu adekwatnych warunków do uczenia się, i kształcą je najczęściej samodzielnie, bez korzystania z oświatowej oferty szkół, zarówno publicznych, jak i niepublicznych" (Budajczak, 2008: 107).

Mimo pozorów niezbędności i wobec przekonania, że odpowiednie uwagi skutecznie pomieszczono $\mathrm{w}$ innych tekstach autora, poniechane zostaną szczegółowe wyjaśnienia co do stale zgłaszanych, stereotypowych wątpliwości względem tej domowej formy edukacji, którymi są kolejno:

- brak możliwości zabezpieczenia w rodzinnym domu (dla większej części populacji zaś i literalnie w rodzinnym mieszkaniu) warunków o „prawidłowej” socjalizacji dziecka (szczególnie o jego uspołeczniania się w szerszych kręgach rówieśniczych);

- brak formalnych kompetencji metodycznych (nauczycielskich), a nawet wyższych kompetencji poznawczych (dokumentowanych dyplomem ukończenia studiów) u tzw. „przeciętnego” rodzica;

- brak kontroli społecznej nad poczynaniami i ewentualnymi zaniedbaniami ze strony rodziców edukacji domowej.

Wszystkie te wątpliwości stanowią, jak się autorowi wydaje, jedynie negatywne, a bywa, że i destrukcyjne w swoich społecznych konsekwencjach, mity, o konieczności stosowania w edukacji wobec wszystkich dzieci i rodzin procedur instytucjonalizacji, certyfikacji i państwowego nadzoru, mity oparte na niezweryfikowanych założeniach, z którymi łatwo dyskutować za pomocą empirycznych dowodów (por. Budajczak, 2004).

A czym w ogóle jest w swojej funkcjonalności mit? Jak wydaje się na podstawie badań literatury przedmiotu, można wyróżnić dwie „odmiany” mitu: negatywną i pozytywną. Negatywny, często też destruktywny, mit to zafałszowanie pewnego wymiaru rzeczywistości, wydumana (bo usilnie argumentatywnie racjonalizowana) fikcja, oparta na potocznych lękach i pragnieniach danego „mitotwórcy”, związanych z empirycznymi obiektami i zdarzeniami. Pozytywny, a więc konstruktywny mit to rozbudowana metafora, narracyjna forma opisu świata, ułatwiająca człowiekowi przez owe empiryczne obiekty i zdarzenia ogarnięcie sensu bardziej „eterycznego” zjawiska czy wymiaru świata. 
I tak, w zasobach starożytnych mitologii, a więc i metaforyki różnych kultur, znaleźć można kategorię „insekty”. Pamiętamy zapewne dobrze z naszego grecko-rzymskiego dziedzictwa opowieść o losie nieszczęsnej Arachne, przemienionej w pająka przez zawistną bożą rywalkę po zawodach w dziedzinie tkactwa, a nieco słabiej historię Titonosa, partnera Eos-Jutrzenki „różanopalcej”, który pozostając nieśmiertelnym, nie został jednocześnie obdarzony wieczną młodością, zestarzał się więc i skurczył tak dalece, że trzeba go było zmienić w świerszcza. „Mucha w smole" i „szczebrzeszyński chrząszcz” to popularne, rodzime zastosowania poznawcze „dla” owadów.

$\mathrm{Na}$ metaforę „organizującą” niniejszą diagnozę status quo obecnej polskiej edukacji domowej wybrany został cykl rozwojowy owadów z rzędu jętek (Ephemeroptera) - kuzynek wodnych ważek i motyli - z podgromady owadów uskrzydlonych (Pterygota), które tradycyjnie są uznawane za symbol nietrwałości, „, ulotności”, efemeryczności.

Wskazywane przez zoologów-owadoznawców stadia rozwojowe u jętek to kolejno:

- naiada (funkcjonująca też w starogreckiej mitologii jako „wodna rusałka”)

- stadium larwy, faza inkubacyjna;

- subimago - stadium poczwarki;

- imago - postać owada dojrzałego².

U jętek - co jest dla ich metaforycznej „mocy” interesujące - owe fazy rozwojowe są fizycznie co do wyglądu niewiele od siebie różne.

Tu możliwym staje się postawienie pytania: czy za pomocą charakterystyki któregoś z wymienionych stadiów biografii przeciętnej jętki majowej możliwym byłoby metaforyczne „opisanie” kondycji edukacji domowej jako legalnej możliwości i/lub ruchu społecznego w dzisiejszej Polsce? Gdyby zaś takie podejrzenie miało okazać się trafnym, to rodzi się kolejne pytanie: czy odpowiednikiem byłaby dla aktualnego stanu ruchu polskiej domowej edukacji jej faza „embrionalna”, faza „młodociana”, czy raczej faza „dojrzałości”?

Oto propozycja odpowiedzi na postawione wyżej pytania:

1. Przy arbitralnym charakterze przyjmowania założenia o adekwatności obranej metafory do reprezentowanej danej kwestii niniejszym przyjmuje się, iż możliwość wykorzystania metafory "jętki” do status quo polskiej edukacji domowej oczywiście zachodzi. Kolejno trzeba więc rozstrzygnąć kwestię drugą. I tak: w opisie kondycji współczesnej krajowej edukacji domowej nie będzie raczej metaforycznie użyteczną rozwojowa faza "najady”, choć edukacja domowa w Polsce trwa zaledwie 19 lat (jak na zjawiska społeczne to okres stosunkowo niedługi) i przeszła kilka metamorfoz, a możliwe też, że w niektórych elemen-

${ }^{2}$ Zob. np. http://en.wikipedia.org/wiki/Mayfly. 
tach strukturalnych będzie się dalej „przepoczwarzać” (w oryginale, u jętek w tej fazie rozwoju jest to seria 20-30 wylinek, trwająca od kilku miesięcy do kilkunastu nawet lat).

2. Nie będzie dla edukacji domowej porównawczo adekwatną także faza „imago" - stadium dorosłej postaci jętki - ponieważ bodaj nic nie jest we współczesnej polskiej domowej edukacji ani ostateczne, ani względnie stabilne, jak to się ma z dojrzałością nie tylko u "robaków” (u jętki ta faza życia trwa od 30 minut do maksymalnie jednego dnia - stąd epitet przydawany temu gatunkowi: jętka jednodniówka!). W dalszym ciągu edukacja domowa może jeszcze w zakresie prawa podlegać w naszym kraju nowelizacyjnym zmianom (ewolucji?), a ruch społeczny edukacji domowej, szczególnie w porównaniu do jego amerykańskiego odpowiednika, ciągle jest nieustabilizowany.

3. Jeśli więc nie w żadnym ze stadiów skrajnych, to może polska edukacja domowa znajdować się jedynie w środkowej, a co do jakości, w szczególnej fazie własnego rozwoju, jaką jest dla jętki: subimago. Entomologowie opisują takie cechy owego "niedojrzałego” stadium rozwoju tego owada, jak brak zdolności prokreacyjnych i kiepskie kompetencje w lataniu.

Jako obserwator dzisiejszej polskiej edukacji domowej autor mógłby, jak się wydaje, wskazać na przesłanki uzasadniające tezę o braku u niej prokreacyjnego, twórczego potencjału do „rozmnażania się” (znaczącego poszerzania się ilościowego i jakościowego) oraz o braku w niej zdolności do „wzlotów”, do optymalizowania własnej kondycji w warunkach dzisiejszego polskiego społeczeństwa.

Jakie miałyby zatem być przyczyny tak postrzeganej aktualnej bezpłodności czy ,jałowego biegu” (to równie adekwatna w tym miejscu, choć techniczna metafora) współczesnej polskiej edukacji domowej? Jak się wydaje, są to jednocześnie przyczyny natury „wewnętrznej”, dotyczącej samego społecznego środowiska edukacji domowej, jak i natury „zewnętrznej” - w postaci społecznie generowanych w Polsce warunków uprawiania edukacji domowej.

Jeśli słowo: „kompleks” literalnie oznaczało w łacinie „węzeł” i trudne do rozwikłania „splątanie”, to w różnych konotacjach obecna polska edukacja domowa "ma” kompleksy i „jest” spętana, po "gordyjsku” wręcz zawęźlona. Wewnętrzne blokady stanowią, przynajmniej dla części osób w domowe nauczanie zaangażowanych - zarówno rodziców, jak i jego aktywistów - zauważalne „specyficzności” ich natury psychologicznej (wśród najbardziej szkodliwych wskażmy np. skłonność do forsowania, nawet opartego na świadomym „poświadczaniu nieprawdy”, reklamiarstwa, uprawianego „dla dobra edukacji domowej”, a przy tym skłonność do zabiegania o osobistą autopromocję), pragnienia i wynikają- 
ce z nich przedsięwzięcia natury mikroekonomicznej (próby zarobkowania „na” edukacji domowej mimo jej demograficznej mikroskopijności), tendencje mikropolityczne i mikrokulturowe (tu m.in. przekonanie o posiadaniu „patentu” na prawdę o edukacji i określonej „legitymacji” do sprawowania kontroli nad innymi), a więc jakości właściwie pozaedukacyjne i niespecjalnie - to prawdopodobny eufemizm - licujące $\mathrm{z}$ dobrem edukowanego w domu dziecka. Zewnętrzne ograniczenia stanowią „pęta" kulturowe i polityczne narzucane edukacji domowej, możliwe do sprowadzenia do czegoś, co określić można mianem społecznej hubris, z jednej strony będącej egoistyczną indywidualną krótkowzrocznością co do walorów legalnego przecież sposobu zaspokajania potrzeb przez innych obywateli, oraz motywowaną grupowym interesem (także ekonomicznym) hyperopią „licencjonowanych specjalistów”, z drugiej zaś racjonalistyczną pychą państwa (w tym jego oświatowych elit), wraz z nieodłącznym od nich obu, jeśli wolno tę kwestię tak relatywizować, socjobiologicznym w charakterze, popędem dominacyjnym.

Oto dwa przykłady tekstów wykazujących takież indywidualne i zbiorowe motywacje (wcześniejszy - bardziej metaforyczny), które skutkują utrudnieniami, jakich doświadcza właśnie współczesna polska edukacja domowa.

Pierwszy z tych fragmentów pochodzi ze znanego miłośnikom poważniejszej beletrystyki - choćby z pseudoludowego tańca sirtaki, zawartego w jego filmowej adaptacji, a filozofującego na temat edukacji do „mądrości życia” utworu Nikosa Kazantzakisa pt. Grek Zorba. Fragment ten zawiera - nomen omen - uwagi na temat należącego do tej samej zoologicznej podgromady, co jętki, rzędu Lepidoptera, tj. motyli:

Przypomniałem sobie pewien ranek, gdy zobaczyłem uczepioną kory drzewa poczwarkę właśnie w chwili, gdy motyl rozrywał spowijającą go powłokę, przygotowując się do lotu. Czekałem dość długo, ale motyl zwlekał. Niecierpliwie schyliłem się i zacząłem go ogrzewać własnym oddechem. I w moich oczach - szybciej, niż przewiduje natura - zaczął dokonywać się cud. Powłoka opadła i wyszedł motyl, ale... kaleki. Nigdy nie zapomnę przerażenia, jakie odczułem, gdy zobaczyłem, że nie może rozwinąć skrzydeł. Drżąc próbował tego dokonać wysiłkiem całego ciała - na próżno, choć pomagałem mu oddechem. Potrzebny był tu cierpliwy proces dojrzewania. Skrzydła powinny wolno rozwijać się w słońcu. Teraz było już za późno. Ciepło mojego tchnienia zmusiło go, aby opuścił poczwarkę przedwcześnie, pomarszczony niczym embrion. Drżał rozpaczliwie jeszcze chwilę i... umarł na mojej dłoni (Kazantzakis, 1971: 106-107).

Komentarz wydaje się tutaj zbędny. I fragment drugi:

Wierzę, że każdy nauczyciel winien uświadamiać sobie powagę swego powołania; że jest oto społecznym funkcjonariuszem, delegowanym do podtrzymywania właściwego porządku społecznego i zapewniania słusznego społecznego rozwoju.

Wierzę, że w ten sposób nauczyciel zawsze jest prorokiem prawdziwego Boga i odźwiernym do prawdziwego królestwa Bożego (Dewey, 1897: 77-80). 
Powyższy cytat to dwa ostatnie punkty Artykułu Piątego, zatytułowanego „Szkoła a społeczny postęp", ze znanego teoretykom i badaczom edukacji, a także studentom pedagogiki, dziełka Johna Deweya Moje pedagogiczne credo.

Kłopot $\mathrm{z}$ tą wypowiedzią polega na tym, iż J. Dewey jako „democratic socialist” (jak sam siebie mianował) był zdeklarowanym... ateistą. Jego „Bóg” to prawdopodobnie odmiana platońskiego „rządu mędrców”, oświeconych elit państwa, a „królestwo Boże” to doskonale, inżynieryjnie zarządzane społeczeństwo. Jest to bodaj ten sam rodzaj dobrego moralnego, a także politycznego samopoczucia, jaki prezentują funkcjonariusze państwowego systemu oświaty w Polsce.

Owadzie „subimago" może przekształcić się w dojrzałe „imago” i przekazać „życie" dalej. Polska, a szerzej także europejska, edukacja domowa tymczasem nie mogą żywić takiej nadziei! I trudno gdzieś szukać pomocy, kiedy i sądy (w tym także Europejski Trybunał Praw Człowieka), które winny strzec demokratycznej praworządności w zakresie „praw człowieka”, w kwestii edukacji domowej wydają się tracić poczucie ludzkiej rzeczywistości.

A może jednak wszystko to, co wyżej powiedziano, jest tylko percepcyjnym złudzeniem, wykreowanym przez nadmierne zaufanie metaforom? Może nie należy się w życiu społecznym, a szczególnie w nauce, a stąd i w naukach o edukacji, ich uwodzicielskim sugestiom poddawać?! Cóż jednak, poza jałowymi liczbami, pozostałoby nam w zamian?!

\section{Literatura}

Budajczak M. (2004). Edukacja domowa. Gdańsk

Budajczak M. (2010). Edukacja domowa. [W:] Encyklopedia pedagogiczna XXI wieku. (red.)

T. Pilch. Warszawa

Dewey J. (1897). My Pedagogic Creed, „School Journal”, Vol. 54 (January)

Kazantzakis N. (1978). Grek Zorba. Warszawa

Lakoff G., Johnson M. (1988). Metafory w naszym życiu. Warszawa

http://en.wikipedia.org/wiki/Mayfly 


\section{On the Condition of Polish Home Education as a Social Subimago (or on Dangers of Metaforization)}

\section{Summary}

Home education is a kind of alternative education where parents or legal custodians of a child voluntarily take responsibility on themselves to provide their child the adequate conditions to learn and teach him/her independently without using the educational offer of schools, neither public, nor non-public ones.

For it is possible to be found elsewhere, the author was not going to answer the stereotypical doubts concerning home education, namely:

- the lack of „proper” conditions for socialization of a homeschooled child (and especially contacts with his/her equals);

- the lack of formal teaching competences or even college diplomas for the part of parents;

- the lack of social control (supervision) over the parental deeds in homeschooling.

All those doubts seem to be very social myths. And what are myths like in their essence? Let's divide myths into the opposition: positive (constructive) and negative (destructive) ones. Within a few European mythologies one can find „insects” as important metaphors (eg. Arachne, Titonos from the Greek mythology).

So the author has chosen „the development cycle of mayfly (Ephemeroptera)" as an organizational metaphor for the analysis of Polish home education status quo. The question was posed what phase of the individual mayfly lifecycle describes the current state of Polish home education best? Is it a naiade (larvae stage), subimago (pupa stage) or imago (the insect in its mature form) phase of the homeschool movement?

According to the research by the author the Polish home education is in its subimago phase, being reproductively sterile (not able to sustain its life), and weak in its flying competences (without power to optimize its social functioning).

The reasons for such a statement are also presented. There are some internal and external barriers damaging the evolution of Polish homeschool movement. The whole complex consists of negative (from the point of a homeschooled child's good) motivations of homeschooling parents, and obstructive or even destructive influences from external agents, and particularly public education officers as the most important. Both kinds of pressures are specific forms of hubris not taking into account the well-being of a homeschooled child or teen. Yet the social conceit is much harder to be managed by a homeschool family and the child him/herself. follows:

In the last two paragraphs of his tiny text „My Pedagogic Creed” John Dewey writes as

I believe that every teacher should realize the dignity of his calling; that he is a social servant set apart for the maintenance of proper social order and the securing of the right social growth.

I believe that in this way the teacher always is the prophet of the true God and the usherer in of the true kingdom of God. 
John Dewey however was a declared atheist and democratic socialist, as he called himself. His "God" and „paradise” were the social state with dominance of social elites members over the simple people treated as justified. Education was (and maybe is) to tell the people to act for the good of those elites. In such a condition the future of Polish homeschooling and not only is not clear as to possibility to mature. 